\title{
JOHN GABRIEL STEDMAN'S COLLECTION OF 18TH-CENTURY ARTIFACTS FROM SURINAME
}

In STEDMAN's famous Narrative (1796), several pages are devoted to a description of the material life of African slaves and free Indians, as he witnessed it during his 'five years' expedition' to Suriname in the 1770s. His book also contains invaluable engravings, made after his own drawings, of a number of artifacts: twentyfour examples of 'arms, ornaments and furniture of the Indians,' in Plate 40 (with an item-by-item description in the text) and eighteen examples of 'musical instruments of the African Negroes,' in Plate 69 (with even fuller item-by-item descriptions).

To our knowledge, scholars have long assumed that the actual artifacts depicted by STEDMAN were simply sketched in situ, or, if they were collected, had long since disappeared. It was with great excitement, then, that we recently came upon 'archival' materials permitting us to trace the history of these pieces, and to locate some of them in the Rijksmuseum voor Volkenkunde in Leiden, where they have been stored, with no indication of their provenience or importance, since 1883 .

For students of Bush Negro art, the Rijksmuseum voor Volkenkunde represents an important repository, in particular, perhaps, because of its large ' 360 series,' which formerly constituted the ethnographic portion of the Koninklijk Kabinet van Zeldzaamheden (Royal Cabinet of Curiosities). ${ }^{1}$ In 1970, JeAN HuRAult published three calabashes from this 360 series (1970: Plates III-VI) and identified them as 'objects collected at the end of the 18th century among black plantation slaves in Suriname' (1970: 115), thus suggesting that these represented some of the earliest extant ex- 
amples of Afro-Suriname art. When we visited the museum, however, the Director, P.H. POTT, assured us that there in fact existed no documentation which would date any Suriname object in the collection before 1816, and that two of the three objects pictured by Hurault (his Plates IV-VI, Leiden's 360-7071 and -7104) belonged to a portion of the series for which there existed no accession documents at all (see below). For these, he explained, one could establish only that they had been deposited in the Dutch Royal Cabinet of Curiosities at some time between 1816 and 1883, when they were then transferred to the Leiden museum. ${ }^{2}$ It was in the subsequent investigation of a calabash rattle (360-1602), that turned out to be the one pictured in HURAULT's Plate III, that we began exploring the circuitous trail which eventually led us to the Stedman collection. ${ }^{3}$

A bit of museum history may be helpful as background for an understanding of our 'search.' Between 1816 and 1883, the Royal Cabinet of Curiosities (which was officially established in 1823 in the Mauritshuis in The Hague) accumulated a varied collection of ethnographica from around the world. By 1883, when this collection was transferred en bloc to the Rijksmuseum voor Volkenkunde in Leiden, it consisted of over 10,000 items. Preparatory to this transfer, in 1880, an inventory was prepared and each object assigned a number. For objects numbered 1-6128, the descriptions that were placed in the inventory book (provenience, function, and so forth) were copied, insofar as possible, from letters, deeds, and other documents written at the time that each object was acquired by the Royal Cabinet. (For objects after no. 6128, which are listed in vol. II of the inventory, no accession documents were available, and the descriptions were made 'at sight' by the cataloguer.) Today, the two-volume handwritten inventory book, as well as the original accession documents relating to the first 6128 objects, are available at the museum. The 10,444 numbered objects that comprise this collection are all prefixed by the series number ' 360 ,' which identifies this collection as the 360th to be logged into the museum's records.

Although the research trail from the aforementioned calabash rattle to the Stedman collection was rather indirect, a summary recapitulation of it bears relevance for an understanding of the cur- 


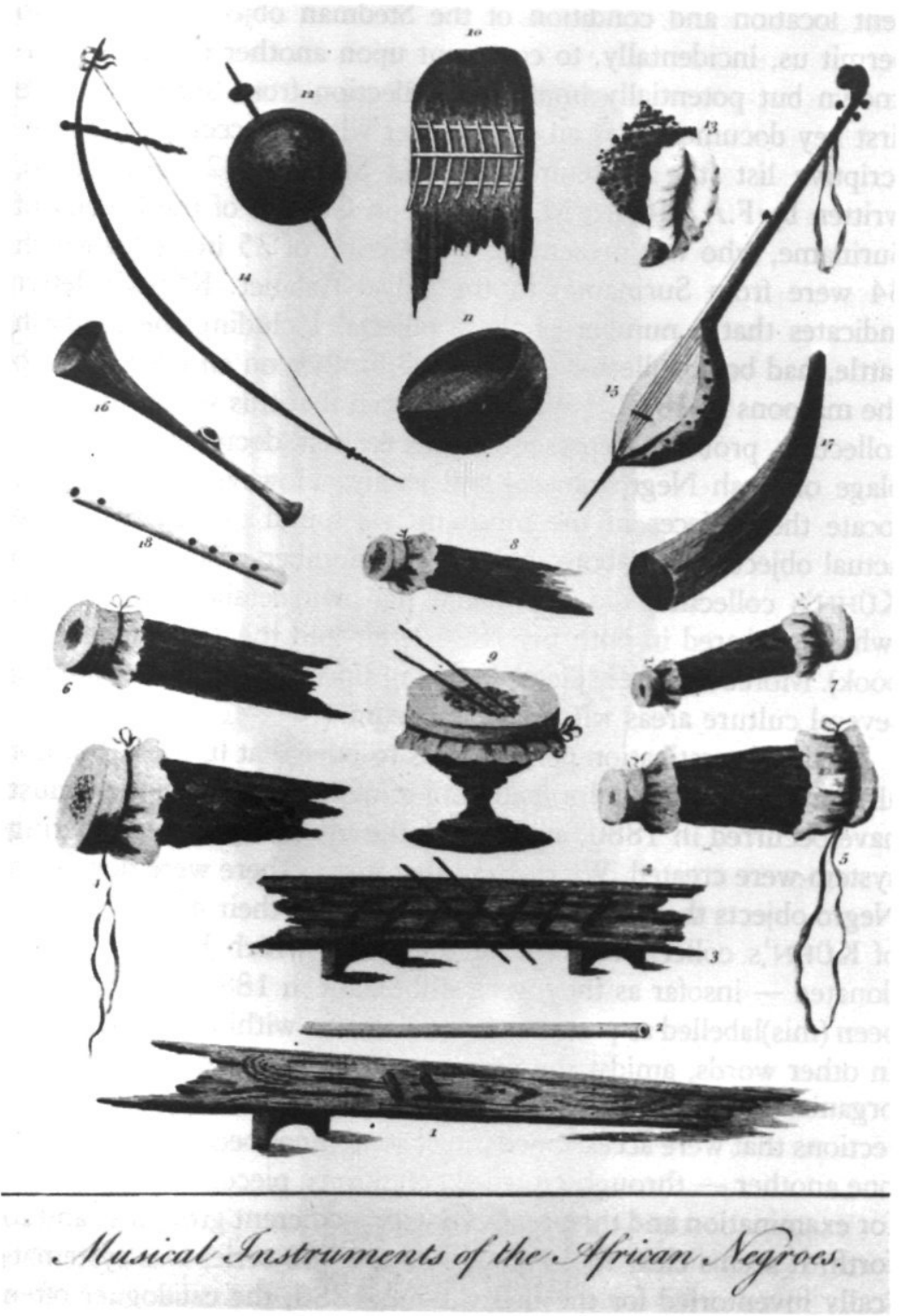

Plate 1. Engraving from STEDMAN's Narrative, 1796 (Pl. 40). 
rent location and condition of the Stedman objects. It will also permit us, incidentally, to comment upon another previously unknown but potentially important collection from Suriname. The first key document was an 1824 letter with an accompanying descriptive list (the museum's Archief Stukken 123 and 123a), written by F.A. KÜHN, M.D., Surgeon General of the Colony of Suriname, who was presenting a collection of 35 items (of which 34 were from Suriname) to the Royal Cabinet. KÜHN's letter indicates that a number of these objects, including the calabash rattle, had been collected 'by my late brother on an expedition to the maroons in 1818.' ${ }^{4}$ We then realized that this small 'maroon' collection probably represented the earliest documented assemblage of Bush Negro objects still extant. However, in trying to locate these pieces in the museum, we found that many of the actual objects which bore the museum numbers corresponding to KÜHN's collection did not match his own detailed descriptions (which appeared in both his 1824 letter and the 1880 inventory book). Moreover, these pieces had long since been dispersed among several culture areas within the museum.

Further investigation permitted us to infer that in most (but not all) such cases, the faulty matching of object and description must have occurred in 1880 , at the time the inventory and numbering system were created. We realized that just as there were non-Bush Negro objects that had been (mis)identified by their number as part of KÜHN's collection, some of the pieces which KÜHN actually donated - insofar as they were still extant in 1880 - must have been (mis)labelled as part of other collections within the 360 series. In other words, amidst the presumably less than perfect physical organization of the Royal Cabinet's storage facilities, pieces of collections that were accessioned intact sometimes became mixed with one another - through crowded conditions, pieces being removed for examination and then replaced with a different grouping, and so forth. It seems clear to us that when the 360 series was systematically inventoried for the first time in 1880 , the cataloguer often made an 'educated guess' when trying to match a description (deriving from original accession papers) to one of the more than 10,000 objects which confronted him. In order to try to discover those of the Kühn pieces which we - after examining the objects 


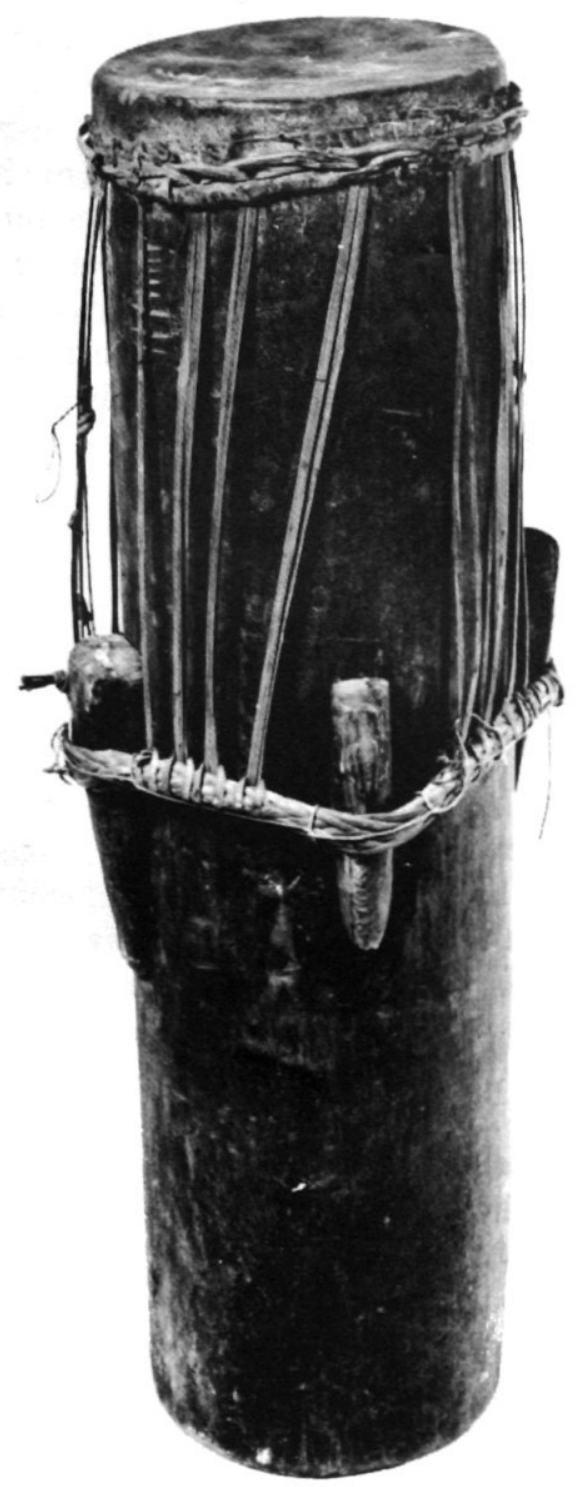

Plate 2. STEDMAN's great Creole drum (360-5685). 
that now bear their inventory numbers - were certain had been given numbers rightfully belonging to other objects in the 360series and placed elsewhere in the museum, we undertook to read through the entire inventory book. That is, we decided to make a systematic search for descriptions in the 1880 inventory referring to potential 'alters' to the Kühn pieces, which might have been inadvertently exchanged with those pieces at the time the numbers were assigned. Because by this point in our research, we had located many of the relevant Kühn objects and concluded that most of the others were no longer to be found in the museum, we focused our inventory read-through on two potentially important pieces a wooden signalling trumpet (tutu) and a long-necked, calabash-based stringed instrument (banja). It was while reading through the inventory book, looking for pieces fitting these descriptions, that we found (among many other such leads which proved eventually to be dead ends) descriptions of some potentially relevant musical instruments, the wording of which we were fortunate to recognize instantly as that used by STEDMAN in his famous 18th-century Narrative.

We were then able to locate the document (Archief Stuk 476) from which these inventory descriptions were copied in $1880-$ a 5-page descriptive list bearing neither date, donor, nor any other explicit link to STEDMAN. The list was filed away among a sheaf of correspondence relating to a very large assemblage of artifacts, mostly from the Far East, that came to the Royal Cabinet in the mid-1820s from J. COCK BLOMHOFF, 'Opperhoofd van Nederlands Handel op Japan.' In the Blomhoff correspondence, we found no reference to this particular list, and therefore do not feel that more than a 'possible' link can be established between the Stedman pieces and BLOMHOFF's larger collection. It is clear, however, that the list did refer to artifacts that its compiler had at hand; though the individual descriptions are taken verbatim from the Dutch translation of STEDMAN's book (1799-1800), three items described by STEDMAN do not appear in the document, and the numbering system there has been adjusted to reflect the absence of these pieces. The list, then, though using STEDMAN's words, enumerates an actual collection of only 39 of the 42 objects which he described and depicted in his Narrative. 


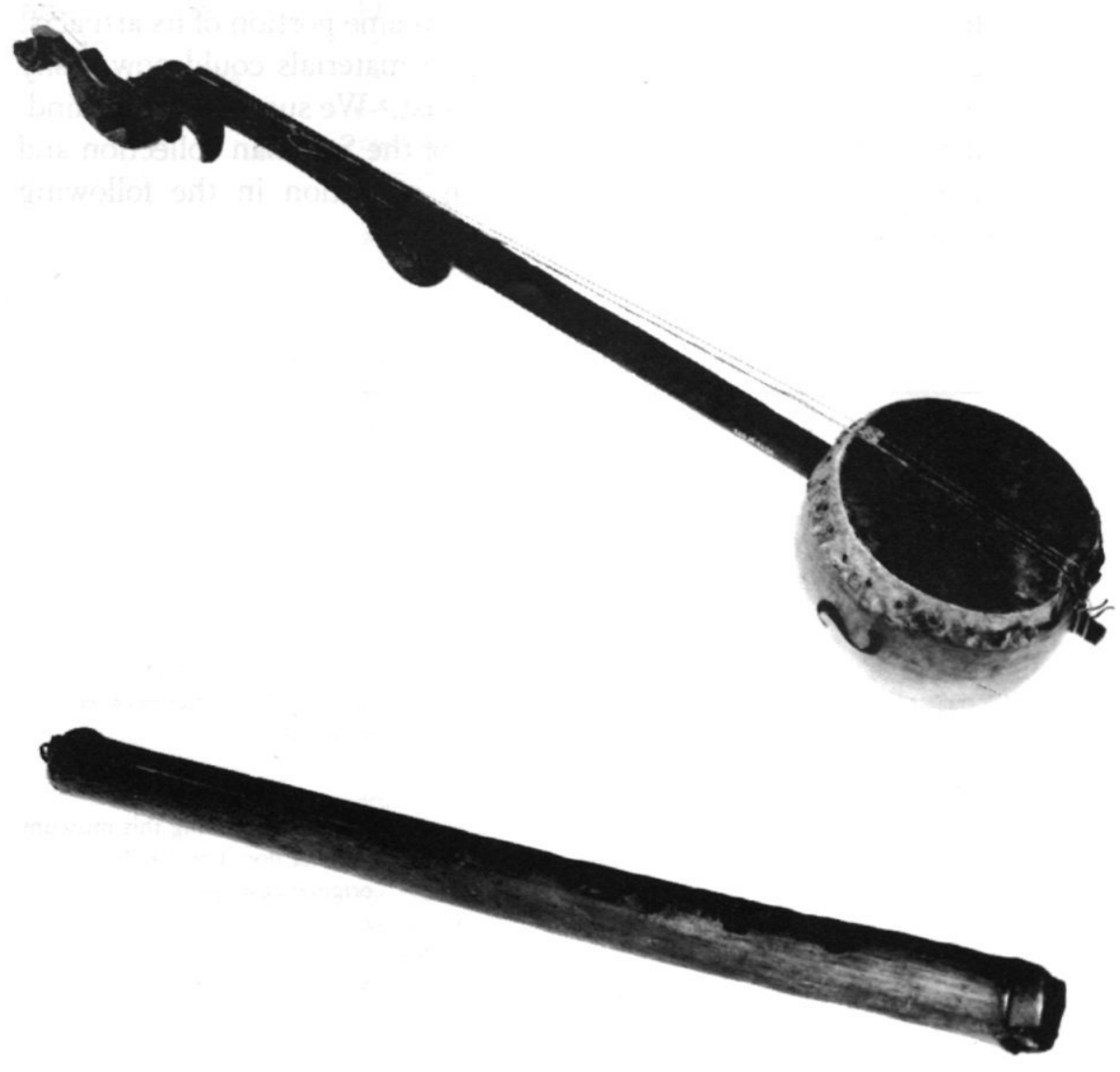

Plate 3. STEDMAN's Creole-bania (360-5696), and Loango too-too (360-5699). 
Because we discovered this collection, as well as that of KÜHN, very near the end of our stay in the Netherlands, we were forced to limit our investigation to the Afro-Suriname portion of its artifacts. Similar research with the Amerindian materials could now easily be undertaken by an interested specialist.' We summarize our findings on the Afro-Suriname portions of the Stedman collection and the 'maroon' portion of the Kühn collection in the following tables.

TABLE 1

THE STEDMAN MUSICAL INSTRUMENT COLLECTION

\begin{tabular}{|c|c|c|c|}
\hline $\begin{array}{l}\text { STEDMAN } \\
\text { no. }\end{array}$ & $\begin{array}{l}\text { Leiden } \\
\text { no. } 360-\end{array}$ & $\begin{array}{l}\text { Original } \\
\text { Description }^{6}\end{array}$ & Remarks \\
\hline 1 & -5682 & $\begin{array}{l}\text { called qua-qua [it] is a } \\
\text { hard sounding board, } \\
\text { elevated on one side } \\
\text { like a boot-jack, on } \\
\text { which they beat time } \\
\text { as on a drum, with } \\
\text { two pieces of iron, or } \\
\text { two bones. }\end{array}$ & $\begin{array}{l}\text { The object bearing this museum } \\
\text { number is totally unrelated to } \\
\text { the original description. It is } \\
\text { made of } 15 \text { wooden slats held } \\
\text { together by two strings, with a } \\
\text { bead on the strings between } \\
\text { each slat. }\end{array}$ \\
\hline 2 & -5683 & $\begin{array}{l}\text { the kiemba-toetoe, or } \\
\text { hollow reed, which is } \\
\text { blown through the } \\
\text { nostrils, like the nasal } \\
\text { flute of Otaheite: it has } \\
\text { but two holes, one at } \\
\text { each end, the one serv- } \\
\text { ing to sound it, the } \\
\text { other to be touched by } \\
\text { the finger. }\end{array}$ & $\begin{array}{l}\text { The object bearing this museum } \\
\text { number does not match the } \\
\text { original description or the en- } \\
\text { graving. It has seven holes, and } \\
\text { can therefore be rejected as } \\
\text { STEDMAN's kiemba-toetoe. }\end{array}$ \\
\hline 3 & -5684 & $\begin{array}{l}\text { the Ansokko-bania, } \\
\text { which is a hard board, } \\
\text { supported on both } \\
\text { sides like a low seat, } \\
\text { on which are placed } \\
\text { small blocks of differ- } \\
\text { ent sizes, which being } \\
\text { struck with two small } \\
\text { sticks like a dulcimer, } \\
\text { give different sounds, } \\
\text { that are not at all dis- } \\
\text { agreeable. }\end{array}$ & $\begin{array}{l}\text { A } 1927 \text { notation in the central } \\
\text { card catalogue and the } 360 \text { - } \\
\text { series inventory book indicates } \\
\text { that this object (which had by } \\
\text { then been classified as part of } \\
\text { the 'Japan and Asia' depart- } \\
\text { ment) had been destroyed (ver- } \\
\text { nietigd). }\end{array}$ \\
\hline
\end{tabular}




\begin{tabular}{lll}
\hline $\begin{array}{l}\text { STEDMAN } \\
\text { no. }\end{array}$ & $\begin{array}{l}\text { Leiden } \\
\text { no. 360- }\end{array}$ & $\begin{array}{l}\text { Original } \\
\text { Description }\end{array}$ \\
\hline 4 & -5685 & $\begin{array}{l}\text { the great Creole drum, } \\
\text { being a hollow tree, } \\
\text { open at one end, and } \\
\text { covered at the other } \\
\text { with a sheepskin, on } \\
\text { which they sit astride, } \\
\text { and so beat time with } \\
\text { the palms of their } \\
\text { hands; answering the } \\
\text { effect of the bass-viol } \\
\text { to the qua-qua board. }\end{array}$
\end{tabular}

\section{Remarks}

Although it is now classified and stored in the West African section, we feel that this drum is quite possibly the one collected and described by STEDMAN. The 'ties' binding the pegs to the drum have long since loosened, but the pegs have been preserved; height of drum $=88 \mathrm{~cm}$ (see plates). It would seem to be one of the two or three oldest Afro-American drums still extant, and a fine complement (in terms of typological contrast) to the famous eighteenth-century Virginia drum now in the British Museum (see EPSTEIN 1977; 49).

5

the great Loango

We have been unable to locate drum, being covered at STEDMAN's two 'Loango' both ends, serves the same purpose as a bass drum.

drums. The two drums which nearly identic size; they are decorated with wooden 'breasts' and have pegs

the small Loango inserted into holes on the sides; with the great one.

they are single-headed - al

of which contrast with

Stedman's drawings. as the others.

Although the inventory book quotes STEDMAN's description under this number, the catalogue card describes the object only as a drum stick ('trommelstok?'). A later notation indicates that this object has been 'written off' (afgeschreven).

the small Creole drum, The drum bearing this number for the same use. is classified in the catalogue (correctly, we believe) as a katambong from Borneo (see also JUYNBOLL 1910: 308). We have no indication of what 


\begin{tabular}{|c|c|c|c|}
\hline $\begin{array}{l}\text { STEDMAN } \\
\text { no. }\end{array}$ & $\begin{array}{l}\text { Leiden } \\
\text { no. } 360-\end{array}$ & $\begin{array}{l}\text { Original } \\
\text { Description }^{6}\end{array}$ & Remarks \\
\hline 9 & -5690 & $\begin{array}{l}\text { called coeroema; this is } \\
\text { a wooden cup, } \\
\text { ingeniously made, } \\
\text { covered also with a } \\
\text { sheep-skin, and beaten } \\
\text { with two small rods or } \\
\text { drumsticks, after the } \\
\text { manner of the qua-qua } \\
\text { board. }\end{array}$ & $\begin{array}{l}\text { The drum bearing this number, } \\
\text { like the previous one, is classi- } \\
\text { fied as (and seems in fact to be) } \\
\text { a katambong from Borneo. We } \\
\text { have no indication of what } \\
\text { happened to STEDMAN's } \\
\text { coeroema. }\end{array}$ \\
\hline 10 & -5691 & $\begin{array}{l}\text { the Loango-bania. This } \\
\text { I thought exceedingly } \\
\text { curious, being a dry } \\
\text { board, on which are } \\
\text { laced, and kept down } \\
\text { by a transverse bar, } \\
\text { different sized elastic } \\
\text { splinters of the palm } \\
\text { tree, like pieces of } \\
\text { whalebone, in such a } \\
\text { manner that both ends } \\
\text { are elevated by two } \\
\text { other bars that are } \\
\text { fixed under them; and } \\
\text { the above apparatus } \\
\text { being placed on no. } 11 .\end{array}$ & $\begin{array}{l}\text { Although these numbers appear, } \\
\text { along with STEDMAN's descrip- } \\
\text { tions, on catalogue cards from } \\
\text { the museum's 'Japan and Asia' } \\
\text { department, the } 1880 \text { Royal } \\
\text { Cabinet inventory lists these }\end{array}$ \\
\hline 11 & -56937 & $\begin{array}{l}\text { a large empty callebash } \\
\text { to promote the sound; } \\
\text { the extremities of the } \\
\text { splinters are snapt by } \\
\text { the fingers, something } \\
\text { in the manner of a } \\
\text { piano-forte, when the } \\
\text { music has a soft and } \\
\text { very pleasing effect. }\end{array}$ & $\begin{array}{l}\text { objects as unlocatable } \\
\text { (ontbreekt). }\end{array}$ \\
\hline 12 & $-5692^{7}$ & $\begin{array}{l}\text { called by the negroes, } \\
\text { saka-saka, being a } \\
\text { hollow gourd, with a } \\
\text { stick and handle fixed } \\
\text { through it, and filled } \\
\text { with small pebbles and } \\
\text { pease, not unlike the } \\
\text { magic shell of the } \\
\text { Indians. This they } \\
\text { hold above their heads, }\end{array}$ & $\begin{array}{l}\text { The long-handled rattle bearing } \\
\text { this number is covered with } \\
\text { netting and numerous small } \\
\text { shells, and thus does not appear } \\
\text { to be STEDMAN's. A new } \\
\text { description was added to its } \\
\text { catalogue card in } 1951 \text {, and it } \\
\text { was classified as 'Ashanti.' }\end{array}$ \\
\hline
\end{tabular}




\begin{tabular}{lll}
\hline $\begin{array}{l}\text { STEDMAN } \\
\text { no. }\end{array}$ & $\begin{array}{l}\text { Leiden } \\
\text { no. 360- }\end{array}$ & $\begin{array}{l}\text { Original } \\
\text { Description }\end{array}$ \\
\hline 13 & -5694 & $\begin{array}{l}\text { a conch, or sea shell, } \\
\text { which by blowing they } \\
\text { sound, for pleasure, or } \\
\text { to cause an alarm, \&c. } \\
\text { but is not used as an } \\
\text { accompaniment to } \\
\text { dancing. }\end{array}$ \\
& $\begin{array}{l}\text { called benta, being a } \\
\text { branch bent like a bow } \\
\text { by means of a slip of } \\
\text { dry reed or warimbo; } \\
\text { which cord, when held } \\
\text { to the teeth, is beaten } \\
\text { with a short stick, and } \\
\text { by being shifted back- } \\
\end{array}$ \\
& $\begin{array}{l}\text { wards and forwards } \\
\text { sounds not unlike a } \\
\text { jew's harp. }\end{array}$
\end{tabular}

\section{Remarks}

This object was listed as

unlocatable at the time of the 1880 Royal Cabinet inventory.

This object was 'written off' (afgeschreven) some time after its transfer from the Royal Cabinet.
Although the central catalogue assigns this object to the 'Japan and Asia' department and gives it no specific provenience, the object itself (as well as correct data on provenience) is located in the South American department. Comparison of the museum object with STEDMAN's description and drawings suggests that this is indeed the stringed instrument which he collected. The wooden neck of the banja is now broken off in two places at its carved end and at the peg for its shortest string; length $=83 \mathrm{~cm}$ (see plates). ${ }^{8}$ accompanied by song.

the trumpet of war, to The central catalogue assigns command advancing, this object to the 'Japan and retreating, \&c, ...called Asia' department, and indicates

by the negroes the that it is stored in the Siberian too-too. collection. We were unable to locate either the object or its catalogue card in these areas of the museum. 


\begin{tabular}{|c|c|c|c|}
\hline $\begin{array}{l}\text { STEDMAN } \\
\text { no. }\end{array}$ & $\begin{array}{l}\text { Leiden } \\
\text { no. } 360 \text { - }\end{array}$ & $\begin{array}{l}\text { Original } \\
\text { Description }^{6}\end{array}$ & Remarks \\
\hline 17 & -5698 & $\begin{array}{l}\text { a horn used to supply } \\
\text { the place of the other, } \\
\text { or on the plantations } \\
\text { to call the slaves to } \\
\text { work. }\end{array}$ & $\begin{array}{l}\text { The horn bearing this number } \\
\text { (now classified as 'Ivory Coast') } \\
\text { appears to be made of ivory } \\
\text { rather than a local Suriname } \\
\text { material and apparently at one } \\
\text { time was encased in animal skin. } \\
\text { It does not appear to be the } \\
\text { object described or drawn by } \\
\text { STEDMAN. }\end{array}$ \\
\hline 18 & -5699 & $\begin{array}{l}\text { the Loango too-too, or } \\
\text { flute, which they blow } \\
\text { as the Europeans do, } \\
\text { after the common way. } \\
\text { It has but four holes } \\
\text { for the fingers, and yet } \\
\text { they make it produce a } \\
\text { variety of sounds. }\end{array}$ & $\begin{array}{l}\text { We believe that this is the object } \\
\text { collected by STEDMAN, though } \\
\text { there is one minor discrepancy } \\
\text { between it and the engraving it } \\
\text { has a square blow hole rather } \\
\text { than a round one. Length }=43 \\
\mathrm{~cm} \text { (see plates). }\end{array}$ \\
\hline
\end{tabular}


TABLE 2

THE KÜHN 'MAROON' COLLECTION

\begin{tabular}{|c|c|c|c|}
\hline $\begin{array}{l}\text { KÜHN } \\
\text { no. }\end{array}$ & $\begin{array}{l}\text { Leiden } \\
\text { no. } 360 \text { - }\end{array}$ & $\begin{array}{l}\text { Original } \\
\text { Description }{ }^{9}\end{array}$ & Remarks \\
\hline 24 & $\begin{array}{l}-1594 \& \\
-1595\end{array}$ & $\begin{array}{l}\text { A bow, with a [bow] } \\
\text { string of the bast of a } \\
\text { tree, and a quiver } \\
\text { containing arrows } \\
\text { [made] from the bast(?) } \\
\text { [bast] of the Areca } \\
\text { palm. The arrows are } \\
\text { dipped in arrow poison } \\
\text { but because of their } \\
\text { age are no longer } \\
\text { dangerous. }\end{array}$ & $\begin{array}{l}\text { Although the central catalogue } \\
\text { assigned the bow (-1594) to the } \\
\text { 'Afrika/America/Australia' } \\
\text { Department, we found no card } \\
\text { for it in any of these three areas } \\
\text { of the museum, and were unable } \\
\text { to locate the object itself. } \\
\text { Under museum number } 360- \\
1595 \text {, there exists a quiver and } \\
22 \text { arrows classified (since 1953) } \\
\text { as 'South Africa, Bushmen.' } \\
\text { On typological grounds, we } \\
\text { consider the attribution of these } \\
\text { latter objects to the Kühn } \\
\text { collection merely 'possible.' } 10\end{array}$ \\
\hline $25 a$ & -1596 & $\begin{array}{l}\text { A spear [werpspies]. } \\
\text { Bush Negro weapon. }\end{array}$ & $\begin{array}{l}\text { The catalogue card for this } \\
\text { object, made in 1959, assigns it } \\
\text { to South Africa and describes it } \\
\text { as a 'Zulu-type spear' (length = } \\
152 \text { cms.). On typological } \\
\text { grounds, its attribution to the } \\
\text { Kühn collections seems } \\
\text { reasonable. }\end{array}$ \\
\hline $25 \mathrm{~b}$ & -1597 & $\begin{array}{l}\text { A lance. Bush Negro } \\
\text { weapon. }\end{array}$ & $\begin{array}{l}\text { The object bearing this number, } \\
\text { formerly classified with South } \\
\text { African materials, has, since } \\
1960 \text {, been attributed to 'West } \\
\text { Sumatra, Batakland or North } \\
\text { Sumatra.' We have seen it and } \\
\text { are convinced that it is not from } \\
\text { Suriname. }\end{array}$ \\
\hline 26 & -1598 & $\begin{array}{l}\text { Staff made from a } \\
\text { forest liana. }\end{array}$ & $\begin{array}{l}\text { Although the card in the central } \\
\text { catalogue contains the inventory } \\
\text { description, taken from KüHN's } \\
1824 \text { list, this museum number } \\
\text { is now written (in handwriting } \\
\text { that identifies it as a post-1880 } \\
\text { addition) on a drum (!) classified } \\
\text { as 'West African,' which does } \\
\text { not even bear any resemblance } \\
\text { to Suriname drums. }\end{array}$ \\
\hline
\end{tabular}




\begin{tabular}{|c|c|c|}
\hline $\begin{array}{l}\text { KÜHN } \\
\text { no. }\end{array}$ & $\begin{array}{l}\text { Leiden } \\
\text { no. 360- }\end{array}$ & $\begin{array}{l}\text { Original } \\
\text { Description } 9\end{array}$ \\
\hline 27 & -1599 & $\begin{array}{l}\text { A horn (blaas riet) } \\
\text { which the Bush } \\
\text { Negroes use to signal, } \\
\text { called by them toe-toe. }\end{array}$ \\
\hline 28 & -1600 & $\begin{array}{l}\text { A musical instrument } \\
\text { of the Negroes, the } \\
\text { body of which is a } \\
\text { covered calabash. It } \\
\text { resembles a kind of } \\
\text { mandolin and the } \\
\text { Negroes call such an } \\
\text { instrument Banja. }\end{array}$ \\
\hline
\end{tabular}

\section{Remarks}

This museum number is now found on two objects: a 'West African' drum and a classic example of a combined spear and blowpipe from Borneo, of which the museum has an excellent collection. We were unable to locate KÜHN's toe-toe elsewhere in the 360-series.

The instrument bearing this number is now classified as 'Mandingo' and closely resembles another 'Mandingo' piece in the museum. It is made of a massive skin-covered gourd, has a large bridge, 16 strings, 2 decorative curved metal spear points (or spades?) pierced along their edges by numerous tiny metal rings, and woven leather rings along its neck. Its length is $130 \mathrm{cms}$. In its bulk and elaborateness, it resembles neither the STEDMAN bania nor any other instrument previously described or depicted for Suriname. We believe that KÜHN's banja (like his toe-toe) was replaced ca. 1880 by an object from another world area, but we were unable to locate it elsewhere in the 360 -series.

A cord, upon which

Although this object is are strung the shells of registered in the South a Suriname fruit, American card catalogue, we Cerbera thevisia. were unable to locate it in Musical instrument of museum storage. the Bush Negroes.
A rattle, sacca sacca, used at Negro dances. The free Negroes and coloreds as well as many slaves have
This small rattle (diam. $9 \mathrm{~cm}$ ) is the one in HuraulT's Plate III. Although we have seen only photographs of it (since the object is on loan to the 


\begin{tabular}{|c|c|c|c|}
\hline $\begin{array}{l}\text { KÜHN } \\
\text { no. }\end{array}$ & $\begin{array}{l}\text { Leiden } \\
\text { no. } 360 \text { - }\end{array}$ & $\begin{array}{l}\text { Original } \\
\text { Description }{ }^{9}\end{array}$ & Remarks \\
\hline & & $\begin{array}{l}\text { among themselves } \\
\text { dance societies... They } \\
\text { call such a group a } \\
\text { Doe, and thus have } \\
\text { the 'gold doe', the } \\
\text { 'silver', the 'amber,' } \\
\text { the 'fashion', and the } \\
\text { 'love' doe. This rattle } \\
\text { belonged to a member } \\
\text { of the Lobi Doe ('love } \\
\text { doe'); the incised } \\
\text { figures are symbolic. }\end{array}$ & $\begin{array}{l}\text { Volkenkundig Museum, Breda), } \\
\text { the similarity of its decorative } \\
\text { incisions to other early } \\
\text { calabashes from Suriname } \\
\text { suggests that it is indeed the } \\
\text { object collected by KÜHN. His } \\
\text { association of this rattle with } \\
\text { the lobi doe indicates, however, } \\
\text { that it may be of non-maroon } \\
\text { Afro-Suriname provenience. }\end{array}$ \\
\hline 31 & -1603 & $\begin{array}{l}\text { A beaded sash, carved } \\
\text { from the shells of } \\
\text { fruits [uit schalen van } \\
\text { vruchten gesneden]. } \\
\text { Musical instrument of } \\
\text { the Bush Negroes. }\end{array}$ & $\begin{array}{l}\text { Although this sash is listed in } \\
\text { the South American catalogue } \\
\text { and described as being } 2.8 \\
\text { meters long, we were unable to } \\
\text { locate it in museum storage. }\end{array}$ \\
\hline 32 & $\begin{array}{l}-1604, \\
1605\end{array}$ & $\begin{array}{l}\text { Pottery dishes. The } \\
\text { Bush Negroes and } \\
\text { Creoles call such a } \\
\text { dish 'prapi.' }\end{array}$ & $\begin{array}{l}\text { These large shallow bowls (diam. } \\
42 \mathrm{~cm} \text {, h. } 12.5 \mathrm{~cm} \text { and diam. } \\
30 \mathrm{~cm}, \mathrm{~h} .10 .5 \mathrm{~cm} \text {, respectively) } \\
\text { were both included in the South } \\
\text { America catalogue and } \\
\text { attributed to Bush Negroes. The } \\
\text { similarity of the objects } \\
\text { themselves to pottery (doti } \\
\text { paabi) still made in a few } \\
\text { maroon villages leaves little } \\
\text { doubt that these are the bowls } \\
\text { collected and described by } \\
\text { KüHN. }\end{array}$ \\
\hline 33 & -1606 & Negro basketry & $\begin{array}{l}\text { One of these three baskets was } \\
\text { exchanged with the } \\
\text { 'Hoofdcursus te Kampen' in } \\
1901 \text {, and another with the } \\
\text { Museo Etnográfico, Buenos } \\
\text { Aires, in } 1910 \text {. We were } \\
\text { unsuccessful in locating the } \\
\text { third basket in the museum. }\end{array}$ \\
\hline 34 & -1607 & $\begin{array}{l}\text { A light basket, called } \\
\text { koeroe koeroe, for } \\
\text { carrying calabashes. }\end{array}$ & $\begin{array}{l}\text { This object was exchanged with } \\
\text { the Reutenstrauch-Joest- } \\
\text { Museum, Cologne, in } 1913 .\end{array}$ \\
\hline
\end{tabular}


In order to encourage further research in these collections, it may be useful to summarize our current understandings (based on our own incomplete research) of the status of KÜHN's 'maroon' artifacts and STEDMAN's 'Musical Instruments of the African Negroes' at the Leiden Museum.

1. Museum numbers on objects which we now believe were actually collected by KÜHN and STEDMAN:11 360-1596, -1602, $1604,-1605,-5685,-5696,-5699$, and possibly -1595 .

2. Museum numbers on objects which we now believe were not part of the original Stedman and Kühn collections: 360-1597, $1598,-1599,-1600,-5682,-5683,-5686,-5688,-5689,-5690$, $-5692,-5698$.

3. Objects listed in the 1880 inventory as 'unlocatable' (ontbreekt): 360-5691, -5693, -5694.

4. Objects listed by the museum as 'destroyed' (vernietigd) or 'written off' (afgeschreven): 360-5684 (vernietigd, 1927), -5687 (afgeschreven, post-1880 notation), ${ }^{12}-5695$ (afgeschreven, post1880 notation).

5. Objects listed as still being in the museum but which we were unable to find: ${ }^{13} 360-1594,-1601,-1603,-1606,-1607,-5697$. 
1. Our research at the Leiden museum formed part of two projects focusing on Suriname maroon art: a study of the history of calabash art among the Saramaka maroons, which will be included in the Ph.D. dissertation of S. PRICE, and a more general book on the arts of the Suriname maroons which we are preparing to accompany a major exhibition scheduled for 1980 ('The arts of the Suriname maroons: a dynamic Afro-American tradition,' Museum of Cultural History, University of California at Los Angeles, supported by a grant from the National Endowment for the Humanities). This research was conducted while R. PRICE was a Fellow at the Netherlands Institute for Advanced Study, and S. PRICE was holding a Fulbright Doctoral Dissertation Research Abroad Fellowhip. R. PRICE also gratefully acknowledges the support of the National Science Foundation under Grant BNS 76-02848. We wish to thank the staff of the Leiden Museum, particularly Professor P.H.PoTT, for their kind assistance.

2. In light of HURAULT's published attributions, it is curious that the contrary factual evidence was so readily available. Not only had the history of this collection been previously published in English (Anon. 1962; see also POTT 1962), but the museum staff is genuinely helpful on such matters. For example, Professor ROBERT FARRIS THOMPSON of Yale University received the same explanation that we did from Professor PoTT during his brief research visit to the museum earlier in 1977 (R.F. THOMPSON: personal communication).

3. HURAULT identifies the objects in his plates only as part of the 360 series, which is comprised of the entire Royal Cabinet collection. Identifying the particular rattle illustrated in HURAULT's Plate III was further complicated by the fact that this object has for some time been on loan to another museum.

4. We found no indication of which group of maroons KÜHN's brother visited, either in museum documents or in KÜHN's book on Suriname (1828).

5. STEDMAN's 21-item Amerindian collection is catalogued in the museum as $360-5661$ through - 5681. Items no. 1, 16, and 18 (a canoe, an earthenware pot, and a hammock) from STEDMAN's published list (1796, I: 406-07; 1799-1800, II: 205-06) are not included in the collection. The following objects from this collection are listed in museum records as unlocatable (ontbreekt): STEDMAN's nos. 2 (360-5661), 5 (360-5664), 9-12 (360-5668 through -5671), and 22 (360-5679). The Amerindian materials collected by KÜHN merit similar attention. They include numbers 360-1563 through -1593; seven pieces of this collection are now listed in museum records as unlocatable, unavailable, or exchanged with another museum.

6. In this table, we quote STEDMAN's original English version (1796, II: 285-87). A Dutch translation of each description appears in the Dutch edition of his Narrative (1799-1800, III: 274-78), in the accession document (ca. 1825) in the museum's archival materials, and in the 1880 inventory book of the Royal Cabinet, presented to the museum in 1883 (see text, above). 
7. The reversal of these two objects (compared with STEDMAN's 1796 list) follows the order of items in the museum's original accession document (see text, above).

8. Note that the 1796 illustration differs from STEDMAN's description (as well as from the instrument itself) in having 5 strings and a tapered point. The fact that its 5 strings lead to only 4 pegs supports our suspicion that this was one of those engravings made from his drawings with which STEDMAN was dissatisfied (see CoLuIS 1965: 221). It would be difficult to overestimate the importance of STEDMAN's Creole-bania, as it represents (to our knowledge) the oldest Afro-American banjo still in existence anywhere, and serves as a fine example of the four-stringed instruments that were made and used at least from the 17th century by Afro-Americans throughout the Hemlisphere (see, for example, EPSTEIN 1977: $1-46)$.

9. We have translated these descriptions from the list accompanying KüHN's 1824 letter. For every item, the 1880 inventory merely quotes this list and adds 'from the Bush Negroes.'

10. Although these short arrows (between 50 and $70 \mathrm{~cm}$ long) bear little resemblance to modern Bush Negro arrows (which are used to hunt fish and are ca. 2 meters long), short arrows were used in war and hunting in earlier times. KüHN, in his 1824 letter, notes that 'the Indians in Suriname use very long bows and arrows. The Bush Negroes... use short bows and small arrows.'

11. Several of these objects (360-1595, $-1596,-5685,-5699)$ belong to a sufficiently large class of typologically similar objects from other culture areas in the museum that an 1880 'mixup' cannot be ruled out. But, in contrast to those objects listed in category 2, we find no positive grounds for questioning the match between the original descriptions in the accession papers and these objects.

12. It was not possible to determine in this case whether it was STEDMAN's 'papa drum' or the 'drum stick' later identified by this number which was 'removed from the books.'

13. We are hopeful that a more exhaustive search of museum storage areas would uncover many of the objects listed here. 


\section{REFERENCES}

Anonymous, 1962. Guide to the National Museum of Ethnology, Leiden. Ministry of Education, Arts, and Sciences, The Hague.

EPSTEIN, DenA J., 1977. Sinful tunes and spirituals: Black folk music to the Civil War. Urbana: University of Illinois Press.

Hurault, Jean, 1970. Africains de Guyane: la vie matérielle et l'art des Noirs Réfugiés de Guyane. La Haye - Paris: Mouton.

JuYnBoll, H.H., 1910. Catalogus van 's Rijks Ethnographisch Museum (Deel II, Borneo). Leiden: E.J. Brill.

KÜHN, F.A. 1828. Beschouwing van den toestand der Surinaamsche plantagieslaven. Amsterdam: C.G. Sulpke.

PoTT, P.H., 1962. Naar wijder horizon, kaleidoscoop op ons beeld van de buitenwereld. 'sGravenhage: Mouton.

StEDMAN, Captn. J.G. 1796. Narrative, of a five-years' expedition, against the revolted Negroes of Surinam. London: J. Johnson and J. Edwards.

Stedman, Captn. J.G., 1799-1800. Reizen naar Surinamen. Amsterdam: Johannes Allart. 


\begin{abstract}
ADDENDUM
After this paper was already in press, we noticed an intriguing entry in the Journal of John Stedman (ed. Stanbury Thompson, London, The Mitre Press, 1962). Written by STEDMAN in early 1796, it reads 'I present Mr. James Parkinson with eighteen Surinam curiosities for his Leverian museum,' and the editor, after describing the museum, adds that 'the many articles of which it was composed, were afterwards sold separately by auction,' and that 'James Parkinson d. Feb. 25, 1813' (p. 392). STEDMAN details these eighteen items later in his Journal (p. 396), and a comparison with the list annexed to the 1796 'arms and ornaments' plate (see above) makes almost certain that a portion — but not all of the pictured items were included in this particular gift to PARKINSON's museum. Finally, we would note that STEDMAN himself made a gift directly to 'his Serene Highness [the Prince of Orange]... for his museum' in 1777 (1796:395).

These historical fragments suggest several new possibilities regarding the ways in which STEDMAN's collection eventually found its way into the Rijksmuseum voor Volkenkunde. We have seen that at least part of the collection came to the Royal Cabinet of Curiosities after the death of PARKINSON, following the auction of pieces in his museum. But the report in STEDMAN's Journal of his gift of some of these objects to PARKINSON, combined with the numerous gaps in STEDMAN's diaries, suggests that the whole of the Rijksmuseum collection may at some time have passed through PARKINSON's hands. On the other hand, the fact that STEDMAN made gifts directly to the PRINCE OF ORANGE in 1777 'for his museum' raises the possibility that he later gave him portions of his Suriname collection directly. It is hoped that further research may some day permit a definitive reconstruction of the history of this collection.
\end{abstract}

Richard and Sally Price, Department

of Anthropology, The Johns Hopkins University,

Baltimore, Maryland 21218. 